\title{
Gender-Biased In The History Textbooks for XI Grade Students Senior High School
}

\author{
MH Fachrurozi ${ }^{1}$, L Armiyati ${ }^{2}$ \\ ${ }^{1,2}$ Department of History Education Universitas Siliwangi, Tasikmalaya, Indonesia \\ ${ }^{1}$ miftahul.habib@unsil.ac.id, ${ }^{2}$ laely.armiyati@unsil.ac.id
}

\begin{abstract}
This study aims to explore the content of gender-bias towards women in history textbooks for XI grade students which published by the Ministry of Education and Culture. This study uses critical discourse analysis method which uses three stages, that are description, interpretation, and explanation. The object of this research is the history textbooks for XI grade students in Curriculum 2013 (revised edition 2017) published by the government. The results showed that the history textbooks in the first and second semesters still contained narratives with gender-bias towards women. The narrative text can be classified into three forms, that are omission, trivialization, and condemnation. The emergence of text narratives containing gender-biased content in textbooks is caused by several factors, among others (1) history textbooks are still trapped in the construction of masculine national historiography, and (2) patriarchal culture which is rooted in Indonesian society that tends to normalization discrimination against women.
\end{abstract}

Keywords: Gender-Bias, Historiography, History Textbooks, Women.

\section{Introduction}

Gender equality is an interesting issue to date, even became one part of the goals of Sustainable Development Goals (SDGs). This happens because there are many cases of gender discrimination that occur, even in an era of increasingly sophisticated digitization. The issue of gender equality refers not only to women but also to men. However, cases of violence against men are lower than women. Based on the record of violence against women (CATAHU), the number of violence in Indonesia tends to increase in 11 years. In 2019 the number of violence against women was 431,471 cases, an increase of $693 \%$ from 2008 [1].

The increasing number of physical violence against women is also accompanied by an increase in online gender-based violence. Through electronic media, the perpetrators could easily harass their victims by hiding his identity. Based on the data of the National Commission on Violence Against Women, in 2019 there were 281 reported the cases, higher than the previous year $(97$ cases). Most cyber cases take the form of threats and intimidation of the distribution of photos or videos of victims. High cases of violence place Indonesia as the most dangerous country for women in the Asia Pacific, along with the Philippines and India [2]. These problems have led activists to urge parliament to pass the bill on the Elimination of Sexual Violence (RUU PKS). In addition to cases of violence, the low level of female labor force participation in Indonesia is also an indicator of not achieving gender equality. Based on World Bank data, Indonesian Women's Labor Force Participation Rate (TPAK) is the lowest in ASEAN, which is 55.5\%, while men's TPAK is $83.18 \%$ [3].

Gender issues in Indonesia still tend to be considered taboo by some people because they think that gender is related to women's dominance. The essence of gender equality is the 
balance of positions and roles between men and women [4]. The issues in Indonesia are closely related to the strength of gender dichotomy in society. This dichotomy triggers gender inequality, which is a system and structure that results in the loss of one gender. [5], [6]. The issue of gender inequality was responded to by the government through the internalization of gender mainstreaming policies in all sectors through Presidential Instruction number 9 of 2000. This policy was expanded by targeting educational institutions as formal strategic institutions to develop gender mainstreaming, through the Minister of National Education Regulation Numb. 84/2008. The Regulation regulates that each work unit in the education sector plans, implements, monitors and evaluates all education development policies and programs to integrate gender in them. Gender mainstreaming education through the issue of discrimination between women and men in education can be addressed by implementing gender equality from the scope of the family to the community [7].

One implementation of gender mainstreaming in schools is through the internalization of gender discourse in textbooks. This is a strategic effort because the textbook is one of the main components of learning. There are only a few research on gender discourse in history textbooks, in the past 5 years there has only been 2 research. In 2016 there was research on the representation of women in Indonesian history textbooks based on the Curriculum 2013 in high school at all levels, using the critical discourse analysis method. The results showed that the position of women as subjects in textbooks was $63.27 \%$ and the position of women as objects was $36.73 \%$ [8]. Subsequent research on gender discourse states that there are a gender bias and marginalization of women in history textbooks published by the Ministry of Education and Culture [9]. Both studies stated that the high school history textbooks Curriculum 2013 edition still contained gender bias towards women. However, none of two studies analyzed gender-bias in the revised edition of history textbooks in 2017, especially in XI grade. Based on the facts above, this study will examine gender biases in the history textbooks for the XI grade senior high school Curriculum 2013 (revised edition in 2017).

\section{Method}

This research is qualitative research with a critical discourse analysis method. Critical discourse analysis is a method that seeks to analyze the interplay between the use of language and elements of social praxis in society. According to Norman Fairclough, there are three dimensions in the analysis of critical discourse, that are text analysis, discursive practice, and social praxis [10]. Text analysis is focused on linguistic analysis of the grammar which is opposed by the text to be analyzed. The discursive practice seeks to uncover content in the text through analysis of the production and consumption of texts. Meanwhile, socio-cultural praxis centered on renewing contexts outside the text, such as contention, or the socio-cultural context of local communities.

The critical discourse analysis method in this research is carried out through three stages, that are description, interpretation, and explanation [11]. The three stages are related to the dimensions of critical discourse analysis. The description phase is carried out by analyzing gender-biased texts in history textbooks. The interpretation phase is carried out by analyzing regulations related to textbook production and the consumption of textbooks by history teachers. While the explanation phase by analyzing the construction value in the textbooks, to do with national historiography as well as the socio-cultural context of Indonesian society. 
The object of this study is the history textbooks for the XI grade senior high school Curriculum 2013 (2017 revised edition) for the first and second semesters which downloaded from buku.kemdikbud.go.id. The selection of that history textbooks is based on the number of narratives that contain gender biases towards women in those books. Data collection by documentation, interviews, and literature study. The documentation technique is done by analyzing regulations regarding the production of textbooks. Meanwhile, interviews were conducted with Dwi Nuryanti and Zafar Zein, the history teachers who used the history textbooks to understand the consumption process of the textbooks. Literature study to analyze texts and socio-cultural praxis that also influence the content of discourse in textbooks.

\section{Results And Discussion}

History textbooks for the XI grade senior high school in first semester consists of four chapters, namely (1) Antara Kolonialisme dan Imperialisme, (2) Perang Melawan Kolonialisme dan Imperialisme, (3) Dampak Perkembangan Kolonialisme dan Imperialisme, and (4) Sumpah Pemuda dan Jati Diri Keindonesiaan. In essence, not all chapters contain text containing gender bias against women. That gender bias can be found at Perang Melawan Kolonialisme dan Imperialisme and Sumpah Pemuda dan Jati Diri Keindonesiaan chapter. The first example can be seen below.

Christina Martha Tiahahu who tried to continue the guerrilla war was finally captured ... He fell ill and finally died on January 2, 1818. His body was dumped into the sea between Buru Island and Pulau Tiga. Thus, Pattimura's struggle ended (page 110) [12].

(Christina Martha Tiahahu yang berusaha melanjutkan perang gerilya akhirnya juga tertangkap ... Ia jatuh sakit dan akhirnya meninggal pada tanggal 2 Januari 1818. Jenazahnya dibuang ke laut antara Pulau Buru dan Pulau Tiga. Dengan demikian, berakhirlah perlawanan Pattimura).

The text illustrates the end of the struggle of a female hero from Maluku named Christina Martha Tiahahu. Interestingly, the writer's statement which states that Christina Marta Tiahahu's death is the end of Pattimura's struggle. Instead of calling the event "the struggle of the Ambonese", the writer prefers the phrase "Pattimura's struggle". This choice of phrases indicates that the more dominant event is the struggle led by a man (Pattimura) and not the struggle of the Ambonese. Meanwhile, Christina Marta Tiahahu's role in the struggle was portrayed in a more inferior position compared to Pattimura as the main figure of the struggle.

Another text can be found at Sumpah Pemuda dan Jati Diri Keindonesiaan chapter, as written below.

....and also the first women's issue published periodically namely the Poetri Hindia (19081913). One known editor is R.M. Tirtoadisuryo ... Also for the advancement of women the Soenting Melajoe magazine was published ... (page 189) [11].

(...dan juga terbitan wanita pertama yang terbit berkala yaitu Poetri Hindia (1908-1913). Seorang editornya yang dikenal yaitu R.M. Tirtoadisuryo ... Juga untuk kemajuan kaum perempuan diterbitkan majalah Soenting Melajoe ...)

Based on the text, the author emphasizes the importance of the press to the progress of the natives in the Dutch East Indies. The author also alluded to some women's press including Poetri Hindia and Soenting Melajoe. One thing that must be supervised in the text is the absence of female journalists in both newspapers. Poetri Hindia was founded by Tirto Adhi Soerjo, but the chief editor was a woman named Raden Ayu Hendraningrat [13]. Meanwhile, 
in Soenting Melajoe, the founder is Soetan Datuk Maharadja, and for managing editorship left entirely to an educated woman who came from Koto Gadang named Siti Rohana Kudus [14]. The absence of representation of female journalists in the emergence and development of the women's press in the Dutch East Indies gives the impression that even though the women's press has emerged, the organizer is still a male journalist. This impression contradicts the historical facts that show that the manager of the women's press is women journalists. Unfortunately, the names of these female journalists did not appear in the history textbooks.

Other text excerpts that contain gender bias towards women can be seen in the following quotation.

It should be understood that the development of young men's organizations is also followed by the development of women's organizations in Indonesia. In 1912 the first women's organization, Putri Mardika, was founded in Jakarta (page 222) [12].

(Perlu dipahami bahwa dengan berkembangnya organisasi di kalangan pemuda juga diikuti oleh berkembangnya organisasi wanita atau perempuan di Indonesia. Pada tahun 1912 berdiri organisasi perempuan yang pertama yakni Putri Mardika di Jakarta.)

Based on the text the writer wants to provide information about the development of women's organizations in Indonesia in the context of the Indonesian national movement. One thing to note is the mention of the phrase " the development of young men's organizations " as an event that started the emergence of women's organizations in Indonesia. The author's description shows that the founding of women's organizations only followed the founding of organizations carried out by young men in previous years. Thus, although the text tells of the founding of women's organizations, the position of men is described as more dominant because they are the initiators of the founding of organizations for young people. The author's description of the founding of the women's organization is certainly questionable. Indonesian national movement organizations that were established in the early phases generally did not recognize gender restrictions. For example, Boedi Oetomo does not limit themself to certain gender restrictions and even seeks to involve women from the Javanese gentry (priyayi) such as Kartini's sisters in achieving these goals [15].

Furthermore, in the second-semester history textbook, there are three chapters cover gender-biased which are Tirani Matahari Terbit, Indonesia Merdeka, and Revolusi Menegakkan Panji-Panji NKRI chapters. Unlike the history textbook in the first semester, each chapter in the second semester contains a gender bias such as the example below.

During the Japanese occupation many Indonesian girls and women who were deceived by the Japanese under the pretext of working as nurses or going to school were only forced to serve the kempetai. The girls and women were held in closed camps as a prostitute (page 50) [12].

(Pada masa pendudukan Jepang banyak gadis dan perempuan Indonesia yang ditipu oleh Jepang dengan dalih untuk bekerja sebagai perawat atau disekolahkan, ternyata hanya dipaksa untuk melayani para kempetai. Para gadis dan perempuan itu disekap dalam kampkamp yang tertutup sebagai wanita penghibur)

The text illustrates the success of the Japanese army in deceiving Indonesian women to served the Kempetai. In the text, it appears that the subject of the sentence is the word "Japanese" which refers to the Japanese army while the word "Indonesian woman" is placed as the object of the sentence. The author in the text describes Indonesian women in a passive condition, meaning that they are objects of the actions carried out by the subjects. The author also does not provide information on how the reactions of Indonesian women who were deceived, whether to resist or just surrender to the treatment of Japanese soldiers. Therefore, it can be concluded if the text depicts Indonesian women as fully passive objects and in full 
control of the subject matter (the Japanese army).

Further examples of text excerpts that contain gender bias against women in the Indonesia Merdeka chapter can be seen below:

During the proclamation ... Latief Hendraningrat assisted by S. Suhud raised the Merah Putih flag, and who helped bring the flag was S.K. Trimurti (page 130) [12].

(Pada saat pelaksanaan proklamasi ... Latief Hendraningrat dengan dibantu S. Suhud mengibarkan Sang Saka Merah Putih, dan yang membantu membawakan bendera Merah Putih adalah SK. Trimurti)

The text describes the events of Indonesian independence proclamation on August 17th 1945. The text focuses on the role of Latief Hendraningrat as the raiser of the Merah Putih flag and other figures such as S. Suhud and a female figure, S.K. Trimurti. Unfortunately S.K. Trimurti in the sentence is in the position of the clause indicating that she is not the main character. The main figure in that procession is Latief Hendraningrat who is positioned as the subject in the sentence. The use of the phrase "who helped bring the flag" also confirms the position of S.K. Trimurti as a mere servant who has a smaller role than the male figure (Latief Hendraningrat). This description certainly undermines the role of S.K. Trimurti around the proclamation of independence. S.K. Trimurti was included young leaders who urged Sukarno and Hatta to immediately proclaim Indonesia's independence. She was also a member of the Central Indonesian National Committee (KNIP) after Indonesian independence. [16].

Texts containing gender biases towards women can also be found in the Revolusi Menegakkan Panji-Panji NKRI chapter. Examples of texts containing gender biases against women from the chapter can be seen below.

Finally the battle raged in Surabaya ... One of the youth leaders, namely Sutomo (Bung Tomo) has established Radio Rebellion to ignite the fighting spirit of the arek-arek Surabaya (Surabaya's people) ... Another figure, for example Ktut Tantri, is an American woman who is also active in airing her revolutionary speeches in English through the Bung Tomo Rebellion Radio (page 155) [12].

(Akhirnya pertempuran berkobar di Surabaya ... Salah satu tokoh pemuda, yaitu Sutomo (Bung Tomo) telah mendirikan Radio Pemberontakan untuk mengobarkan semangat juang arek-arek Surabaya ... Tokoh lain, misalnya Ktut Tantri, yakni wanita Amerika yang juga aktif dalam mengumandangkan pidato-pidato revolusinya dalam bahasa Inggris melalui Radio Pemberontakan Bung Tomo)

The text illustrates the role of figures around the 10th November 1945 battle. The main character depicted by the author in the text is Sutomo who has a dominant role in encouraging the fighting spirit of the people of Surabaya to fight against the British. Meanwhile, the female character named Ktut Tantri was described by the writer in a more inferior position and seemed to only help the struggle carried out by Sutomo.

Classification of texts containing gender bias towards women needs to be done to understand how women are represented in the narration of history textbooks. The representation of women in symbolic narratives based on masculine views can be classified into three forms, namely omission, trivialization, and condemnation [17]. Omission means that women have no room at all in the compiled narration. On the other hand, trivialization has presented women in the narrative but has a small and insignificant role. Meanwhile, condemnation presents women as objects or positioned in a condemned condition. Based on this classification, it can be seen if the discussion about women's press during the national movement was classified as an omission. While the content about the struggle of Christina Martha Tiahahu, the establishment of women's organizations, the role of S.K. Trimurti and Ktut Tantri, are classified as trivialization. Finally, the text about women who were deceived 
during the Japanese period was classified as condemnation. Thus, it can be seen if history textbooks still show some narratives that contain masculine views.

An understanding of the value construction in textbook narratives cannot be separated from the process of producing and consuming textbooks. The government has an important role in the process of producing textbooks. Based on Book System Law Numb. 3 of 2017, the central government is required to provide the primary textbooks that must be used in the learning process in all schools based on the applicable curriculum. This is also reinforced by the Government Regulation on National Education Standards, which positions the central government production textbook as the main source of learning in achieving predetermined competencies (PP Numb. 13 of 2015). The main textbook also includes electronic school books (Buku Sekolah Elektronik - BSE) produced by the government. Thus based on existing regulations, the central government has full control in the preparation and supply of primary textbooks as the main learning resources in schools. The private publisher only gets permission to compile only companion textbooks.

Regulations about the use of history textbooks have generally been complied with by several teachers in schools. This was explained by Dwi Nuryanti, a history teacher at SMAN 1 Merbau Mataram, South Lampung who stated that "using Indonesian History books as a source of learning in the classroom" (Interview July 14, 2020). A slightly different matter was conveyed by Zafar Zein, a history teacher at SMA PGRI 12 North Jakarta who stated that when learning to use "books from the Ministry of Education and Culture subsidies and some private textbooks, as well as student worksheets (LKS) as a means of supporting learning" (Interview July 14, 2020). Thus, it can be seen that in the consumption of history textbooks, textbooks published by the government have been positioned according to its regulations.

The writing of history textbooks is not only intended for educational purposes but also contains political interests. Therefore, the history textbook is certainly closely related to the ideological interest of the states [18]. Thus, history textbooks do not only contain historical knowledge but also must be able to contain ideological values. The relationship between writing history textbooks and the ideological interest of a country has been seen since the early days of Indonesian independence. The absence of history textbooks that were formally compiled by the government resulted in many history teachers developing their teaching material which caused chaos in the teaching of history in the early days of independence [19]. Therefore, the Ministry of Education and Culture then included a discussion on the preparation of history textbooks as one of the agendas in the First National History Seminar in 1957 [20]. The seminar also confirmed the main towards of teaching history in schools as a means of instilling a sense of nationalism for students as well as realizing national unity. The results of the first national historical seminar emphasized the close relationship between political interests and the preparation of historical textbooks.

The writing of textbooks also cannot be separated from the interests of the state in the preparation of historical narratives. The writing of historical narratives, especially national history, has a very close relationship with power. National history writing is not only academic activities but also there are politically meaningful [21]. This can be seen in the preparation of six volumes of the Indonesian National History book which is expected to become the main reference book of national history. The Indonesian National History Book was first published in 1975. Since it was first published, the Indonesian National History book has been introduced as a source of historical learning in the Curriculum 1975 [22]. Although the curriculum was later revised in 1984, the Indonesian National History book remains the main reference in the preparation of history textbooks in high schools even today.

The main characteristic in Indonesian National History Book was the narrative which 
tended to be militaristic and focused on the role of the state in various periods [21]. The compilation of national-centric historical narratives has serious consequences in eliminating several groups in national history. One of the groups that received less attention in writing national history is women. Bambang Purwanto stated that the Indonesian National History book was a historiographical product that consciously or unconsciously ignored the role of women in Indonesian history [23]. This neglect is closely related to the character of writing national history which is dominated by political history and military involvement in the history of the Indonesian people. The involvement of the military in the preparation of historical narratives coincides with gender constructions that strictly separate the roles of men and women [24]. Masculinity is arguably the backbone of national historiography compiled by the New Order. This masculine national historical narrative results in women not getting a proper place in national historiography.

After the New Order collapsed, the issue of women's marginalization in Indonesian historiography continued. According to Thristiawati during the first decade of the reformation era, there were more than 1700 historical-themed books published in Indonesia and only $2 \%$ (34 books) that discussed women [25]. The issue of gender bias in Indonesian historiography did not only occur at the historical writing issued by the state or the work of Indonesian historians. A feminist named Saskia E. Wieringa criticized W.F. Wertheim's book titled Indonesian Society in Transition as a work that does not give much attention to women. She also revealed that Indonesia's historiography has not paid attention to specific gender discussions regarding the role and position of women [26]. This gender inequality ultimately results in the denial of the existence of women both collectively and individually.

Gender-biased is a latent problem in Indonesian historiography and this has become evidence of a patriarchal culture that's deeply rooted in Indonesian society. The connection between Indonesian historiography and patriarchal society can be seen in the silencing of women's activism in the public sphere. The silencing of women's conversion in the public sphere cannot be separated from the New Order version of national historiography which discredited one of the women's organizations, Gerwani. Gerwani considered having political relations with the Indonesian Communist Party (PKI). Therefore, Gerwani also determined the same fate as the PKI which was silenced in historical narratives. The silencing of Gerwani was even wrapped up with metaphors of abnormal sexual activity against the generals in the abduction of 1st October 1965 [27]. This metaphor results in the formation of male hegemony over women in political campaigns. One of the hegemony is seen in the stigma of the collective women's movement or individual women's activists whose morality is often questioned by the people [28]. This stigma attached to activism proves the relationship between gender-biased historiography and patriarchal Indonesian culture.

Patriarchal culture in Indonesian society in the role of legitimizing the dominant role of men against women in the public sphere. Women are only given a role in the domestic realm as well as their opportunities to express themselves in public spaces are very limited. Domestication of women is a natural thing in a patriarchal society. The women's domestication is related to the "kodrat" (nature) of women who are positioned weaker than men. That "kodrat" is used to preserve male domination over women [17]. Thus, as long as this nature is continuously reproduced by society, so long as it is women are in a lower position compared to men. This is a major problem in patriarchal societies that are not recognized by the people and have entered into various realms including history textbooks.

\section{Conclusions}


History textbooks as one of the core components in learning activities, become very potential media to internalize gender equality in schools. However, history textbooks for the XI grade senior high school still found texts containing gender biases towards women whose narratives are classified as omission, trivialization, and condemnation. This is caused by the strong dominance of patriarchal culture which is reflected in social, cultural, and political structures. The dominance of patriarchal culture is a factor in the injustice of women. Injustice towards one gender results in the emergence of a gender gap which leads to social chaos. Therefore, writing history textbooks should naturally avoid the emergence of gender bias through the selection of diction, delivery of narratives, and visualization of historical events. Through these efforts, it is expected to realize the realization of gender equality and justice as the goal of Sustainable Development Goals (SDGs).

\section{Reference}

[1] D. H. Jayani, "Berapa Jumlah Kekerasan terhadap Perempuan?," 2020 . .

[2] A. Evlanova, "Top 5 Safest Countries in Asia Pacific for Women," 2019. .

[3] D. H. Jayani, "Tingkat Partisipasi Tenaga Kerja Masih Didominasi Laki-laki," 2019. .

[4] Laely Armiyati, "Perempuan Berjuang, Bukan Menantang: Studi Gerakan Perempuan Indonesia," in Berbincang Tentang Perempuan dan Pendidikan Untuk Kesetaraan Gender, no. November 2015, Suswandari, Ed. Jakarta: P2TP2A DKI Jakarta, 2015, pp. 390-411.

[5] M. Fakih, Analisis Gender dan Transformasi Sosial. Yogyakarta: Insist Press, 2016.

[6] M. Ali, "Internalisasi Nilai Kesetaraan Gender Dalam Praktik Pendidikan Islam Responsif Gender Oleh: Dedi Wahyudi," vol. 01, no. 02, pp. 83-102, 2019.

[7] E. Tigayanti, M. S. Soeaidy, and R. Nurpratiwi, "Implementasi Kebijakan Pengarusutamaan Gender ( PUG ) Bidang Pendidikan di Kota Malang ( Studi Kasus SMA 8 Malang )," vol. 17, no. 3, pp. 201-208, 2014.

[8] A. M. Briliani, "Analisis Wacana Kritis: Representasi Perempuan Dalam Buku Teks Sejarah Indonesia Berdasarkan Kurikulum 2013 Kelas X, Xi Dan Xii Sekolah Menengah Atas,” Universitas Negeri Malang, 2016.

[9] N. Pranandari, "Bias gender dan marginalisasi perempuan dalam buku teks sejarah SMA (sebuah studi analisis wacana pada buku teks Sejarah Indonesia SMA kelas X), ' Universitas Negeri Malang, 2018.

[10] Haryatmoko, Critical Discourse Analysis (Analisis Wacana Kritis): Landasan Teori, Metodologi, dan Penerapan. Jakarta: Raja Grasindo Persada, 2017.

[11] Eriyanto, Analisis Wacana: Pengantar Analisis Teks Media. Yogyakarta: LKiS, 2012.

[12] Sardiman and A. D. Lestariningsih, Sejarah Indonesia Untuk SMA/MA/SMK/MAK Kelas XI Semester 1. Jakarta: Kementerian Pendidikan Dan Kebudayaan, 2017.

[13] M. H. Fachrurozi, "Politik Etis dan Bangkitnya Kesadaran Baru Pers Bumiputra," Bihari, vol. 2, no. 1, pp. 13-25, 2019.

[14] R. Nuryanti, "Soenting Melajoe," in Seabad Pers Perempuan: Bahasa Ibu Bahasa Bangsa, R. D. A. Yuliantri, Ed. Yogyakarta: I:BOEKOE, 2008.

[15] A. Nagazumi, Bangkitnya Nasionalisme Indonesia: Budi Utomo 1908-1918. Jakarta: Pustaka Utama Grafiti, 1989.

[16] I. Jazimah, "S.K. Trimurti: Pejuang Perempuan Indonesia," Sej. dan Budaya, vol. 10, no. 1, pp. $47-55,2016$.

[17] W. Udasmoro, "Women And The Reproduction Of Literary Narratives In The Construction of Nation," Litera, vol. 16, no. 2, pp. 180-188, 2017.

[18] A. Mulyana, "Nasionalisme dan Militerisme: Ideologisasi Historiografi Buku Teks Pelajaran Sejarah SMA," Paramita Hist. Stud. J., vol. 23, no. 1, pp. 78-87, 2013.

[19] R. M. Ali, "Beberapa Masalah Tentang Historiografi Indonesia,” in Historiografi Indonesia: 
Sebuah Pengantar, Soedjatmoko, R. M. Ali, G. J. Resink, and G. M. Kahin, Eds. Jakarta: PT Gramedia Pustaka Utama, 1995, pp. 1-16.

[20] P. S. Sejarah, Laporan Seminar Sejarah 14-18 Desember 1957 Di Yogyakarta. Yogyakarta: Ombak, 2017.

[21] H. S. Nordholt, B. Purwanto, and R. Saptari, "Memikir Ulang Historiografi Indonesia," in Perspektif Baru Penulisan Sejarah Indonesia, H. S. Nordholt, B. Purwanto, and R. Saptari, Eds. Jakarta: Yayasan Obor Indonesia, 2013.

[22] T. A. Ahmad, Sejarah Kontroversial Di Indonesia: Perspektif Pendidikan. Jakarta: Yayasan Obor Indonesia, 2016.

[23] A. W. Adam, "Perempuan Dalam Sejarah Lelaki," Perempuan, no. 52, pp. 7-18, 2007.

[24] K. E. McGregor, Ketika Sejarah Berseragam: Membongkar Ideologi Militer Dalam Menyusun Sejarah Indonesia. Yogyakarta: Syarikat, 2008.

[25] R. Nuryanti and B. Akob, Perempuan Dalam Historiografi Indonesia. Sleman: Deepublish, 2019.

[26] J. Rizal, "Jejak Perempuan Dalam Historiografi Indonesia,” Perempuan, no. 52, pp. 21-35, 2007.

[27] S. E. Wieringa, Penghancuran Gerakan Perempuan, Politik Seksual Di Indonesia Pascakejatuhan PKI. Yogyakarta: Galangpress, 2010.

[28] L. Suhenty, "Menemukan Sejarah Perempuan Yang (di)Hilang(kan)," Perempuan, no. 52, pp. 37-44, 2007. 